Volume: 02 Issue: 01 | Jan-May-2020

ISSN: $2663-8525$

Received: 07.02.2020; Accepted 10.02.2020; Published: 30.03.2020 at www.editoncpublishing.org

Musyoki, A. Muia et al., Editon Cons. J. Arts., Humanit. S. Stud., Double -Blind Peer Reviewed Journal

\title{
The Impact of the African Inland Mission (AIM) On Social Change between 1895 and 1971 in Machakos District, Kenya
}

\author{
Musyoki A. Muia; Prof. Reuben Matheka; Dr. Mary Chepchieng \\ Egerton University, Kenya \\ Corresponding author email: athanasmuia254@gmail.com
}

\begin{abstract}
This study aimed at analysing the African Inland Mission and social transformation in Machakos District of Eastern Kenya from 1895 to 1971. It sought to establish how the elements of the Akamba social life underwent a social change as a result of the mission's presence in the district. The study was guided by the question: How effective was the mission in influencing social change in the district? The structural- functionalism theory formulated by Herbert Spencer and developed further by Emile Durkheim was used to analyse the role of the African Inland Mission in influencing social change in Machakos District. The qualitative research design involving the use of in-depth interviews with key informants was used. A target population consisting of local residents, former administrators and African Inland Mission/church leaders was interviewed. The study used the purposive method of sampling. Primary data was collected using in-depth oral interviews as well as from archival records, while secondary data was obtained through a thematic review of literature related to the topic of study. This study has provided sufficient knowledge on the African Inland Mission and the social transformation in Machakos District in the colonial and the early post-colonial periods of Kenyan history. In addition, the findings have constituted part of the historiography of the African Inland Mission in Kenya.
\end{abstract}

Key Terms: Mission Station, Social Change, Social Structure

$-* * *$

How to cite this article in APA ( $6^{\text {th }}$ Edition)

Muia, M. A., Matheka, R. \& Chepchieng, M. (2020). The impact of the African Inland Mission (AIM) on social change between 1895 and 1971 in Machakos District, Kenya. Editon Cons. J. Arts., Humanit. S.

Stud., 2(1), 171-186

***

171

(c) 2019, Editon Consortium Publishing | This work is licensed under a Creative Commons Attribution-Non Commercial-Share Alike 4.0 International License. | Website: www.editoncpublishing.org 


\section{Editon Consortium Journal of Arts, Humanities and Social Studies (ECJAHSS)}

Volume: 02 Issue: 01 | Jan-May-2020

ISSN: $2663-8525$

Received: 07.02.2020; Accepted 10.02.2020; Published: 30.03.2020 at www.editoncpublishing.org

Musyoki, A. Muia et al., Editon Cons. J. Arts., Humanit. S. Stud., Double -Blind Peer Reviewed Journal

\section{Introduction}

The African Inland Mission (AIM) was founded by Peter Cameron Scott, a Scottish American missionary who dedicated much of his life to Christian service and evangelisation. As an individual who wished to see many lives brought to Christ, Scott opted to see his dream come to reality by exercising his call mainly in the African continent. His goal was to establish mission stations in the interior of Africa where Christianity had not yet reached. It is no wonder that when Scott came to Africa, he moved inland where he set up mission stations. His attempts to realise this dream started in December 1895 when he established his first station in Africa at Nzaui in what became Machakos District (Kenneth, 1968, p.21). This marked the beginning of the work of the AIM not only in Kenya but also the rest of Africa. Subsequently, the AIM opened more stations in Machakos District such as Sakai, Kilungu and Kangundo before expanding its activities to other parts of Kenya such as Kijabe among the Kikuyu, Laikipia among the Maasai, Eldama Ravine among the Tugen, Kapsabet among the Nandi and Nyakach among the Luo. The mission further expanded its influence to German East Africa in 1909, the Belgian Congo in 1912, Uganda in 1918 and French Equatorial Africa in 1924 (Gehman, 2004, p.129). Recently, the mission has opened stations in Sudan, Namibia, Mozambique, Angola, and Madagascar among other countries in Africa. Machakos District can therefore, be considered as the cradle of the AIM not only in Kenya but also in the African continent.

In Kenya, the AIM existed as a mission from 1895 to 1971. However, since the late 1920s, there was a rising dissatisfaction by African converts over the mission's practices in Kenya (Lionel, 2017, p.39). As a result, the African converts started demanding for the Africanisation of the mission. These demands led to the formation of the African Inland Church (AIC) in 1943. From then on, the AIM and the AIC existed in Kenya up to 1971 as two autonomous bodies but related in their roles. However, more pressure on the AIM to fully Africanise the mission continued. This pressure ended in 1971 when the AIM Field Council under the direction of Frank Frew decided to merge the two organisations. The AIM missionaries now became members of the AIC and subordinate to the church leaders (Gehman, 2004, p.140). The AIM now became a department of the AIC. This marked the end of the AIM activities in Kenya.

Machakos District of Kenya was the cradle of the AIM in Africa. This study analyses how the AIM transformed the Akamba of Machakos District from 1895 to 1971. This is significant because the activities of the AIM in Machakos District have not received much scholarly attention since the establishment of the mission in the district in 1895 up to the time of its merger with the AIC in 1971. Many studies on the AIM have tended to use this district as the starting point of this mission in Kenya before they shift their attention to other areas without showing the social influence of the mission in the district. This study, therefore, is aimed at examining the impact of the mission on social change in Machakos District from the period 1895 to 1971.

\section{LITERATURE REVIEW}

The church in Africa today is a product of the European missionary enterprise that can be dated back to the nineteenth century. Since then, the church has greatly transformed many African societies. This transformation of tropical Africa has mainly been spearheaded by the Christian missionary enterprise (Mugambi, 2000, p.83). Although there are other forces that influenced these social developments in the continent, Christian missions can be identified as having played a critical role in the process of initiating the transformations in the continent. Among these Christian missionary enterprises are the European and the American churches that have been the prime movers of this social transformation in the continent to such an extent that, an attempt to deny or reverse its 


\section{Editon Consortium Journal of Arts, Humanities and Social Studies (ECJAHSS)}

Volume: 02 Issue: 01 | Jan-May-2020

ISSN: $2663-8525$

Received: 07.02.2020; Accepted 10.02.2020; Published: 30.03.2020 at www.editoncpublishing.org

Musyoki, A. Muia et al., Editon Cons. J. Arts., Humanit. S. Stud., Double -Blind Peer Reviewed Journal

effects would utterly be futile (Nasimiyu, \& Waruta, 2000, p.127). From the spread of Christianity to the establishment of health facilities and the introduction of Western education, it can be said that the African societies have been transformed into a different image that was nonexistent before the coming of the Western bound Christian groups.

One way in which the European and the American missionary enterprise brought social change was through the introduction of a new religion among the African communities that it came into contact with. This was mainly realised through the establishment of churches which acted as new venues for propagating the newly introduced religion to the Africans. By doing so, the church would win converts from these communities. The early adherents in these established churches tended to be individuals cut off from their tribes for one reason or another or isolated individuals whose curiosity got the better of them (Anderson, 1970, p.15). Through this, the church would teach the Christian doctrines, which often varied from one missionary group to another. As these African communities welcomed this new religion and its affiliated teachings, there was a gradual shift from the traditional African religious beliefs to the newly introduced Christian beliefs among many members of the communities that the Western affiliated church had come into contact with.

One of these missionary enterprises was led by the AIM. This mission was a non-denominational group under American leadership and strongly influenced by evangelical Baptists and Adventists (Anderson, 1970, p.15). It was established with the objective of reaching the inland parts of Africa to spread Christianity among the many nonChristianised communities of the African hinterland. Consequently, Machakos District of Kenya became the starting point of the mission's Christianisation activities in the African continent. When the mission arrived in the district in December 1895, it established its first three mission stations in Nzaui, Sakai and Kilungu areas of the district (Omulokoli, 1995, p.50). It then spread to other areas of the district such as Kangundo, Mumbuni, Mbooni and Mukaa areas where it established among other institutions, hundreds of churches during its tenure in the district. The church is an important agent of social change in the society where it thrives. As Mugambi has observed, churches have direct contact with individuals and communities at all levels of social fabric and thus subject to influencing these communities (Mugambi, 2000, p.59). However, despite the mission establishing these churches in the district, there is a lack of a sufficient study on the subsequent influences that the churches through the mission brought in the district hence the gap the current study intends to fill.

The introduction of Christianity saw the church bring a remarkable change to various elements of the African's social life. The missionary church viewed African beliefs, norms, traditions and customs as crude and thus it had a duty to transform this. This church did not bother to find out the African religious ideas, thought forms and practices (Okullu, 1974, p.53). Instead, it viewed these African religious ideas and thought-forms as inferior and thus subject to transformation. As Vierra points out, the missionaries took the conventional features of their culture, building churches and schools in the European style and imposing the habits and ethos of the Western Christian civilisation on their converts (Vierra, 2007, p.257). For instance, they introduced church rituals such as the Holy Communion and baptism among the converts, which was a key social innovation among these converts.

This to the African societies was an introduction of new ideas, which prompted them to allow the church to settle in the midst of these African societies, as the Africans were interested with the activities of the church. This would, in turn, bring a change in the society's beliefs and customs 


\section{Editon Consortium Journal of Arts, Humanities and Social Studies (ECJAHSS)}

Volume: 02 Issue: 01 | Jan-May-2020

ISSN: $2663-8525$

Received: 07.02.2020; Accepted 10.02.2020; Published: 30.03.2020 at www.editoncpublishing.org

Musyoki, A. Muia et al., Editon Cons. J. Arts., Humanit. S. Stud., Double -Blind Peer Reviewed Journal

and Machakos District, which was initially a sphere of influence of the AIM, was no exception. However, there is no enough documented evidence to neither show how this mission transformed the beliefs, norms, traditions and customs of the people of this district; hence, the reason for this study.

\section{METHODOLOGY}

This study is based on the historical research design, which is qualitative. This study was carried out in Machakos District of Kenya as it existed before it was split into Makueni and Machakos Districts in 1992. This district was bordered to the West and South by Kajiado District, Kiambu District in the North and to the East by Kitui District. The target population for this study constituted the local residents, the current and the former AIM/AIC leaders and the current and the former administrators such as village elders. The study used the purposive sampling technique, giving an approximate sample of sixty informants. The key informants were identified through church and community leaders. This sample was divided into three categories, each with twenty informants. These categories included twenty former/current AIM/AIC church leaders, twenty local administrators and twenty local residents of Machakos District. To collect primary data, instruments for data collection in the form of interview schedules and observation schedules were developed. The interview schedules were used to obtain information from key informants, while observation schedules were used to collect data from the former AIM establishments and other relics. Recorders and cameras were also used in the collection of audio data and audio-visual data, respectively. Both primary sources (archival documents at the Kenya National Archives and the AIC Archives) and secondary sources (published books, journal articles, newspapers, magazines and seminar and conference papers) were used in this study. Data analysis was carried using analytical frames such as theoretical reflections, content analysis, documentary reviews and chronological analysis for the interpretation of the data.

AIM and Religious Transformation in Machakos District First and foremost, the Akamba traditional religion rotated around ancestral worship with constant reference to a supreme being; mulungu. The AIM initiative to indigenise Christianity among the Machakos Akamba came with a new conception regarding the Supreme Being and the supernatural. Though the new religion recognised the existence of a supreme being just like the Kamba traditional religion, it brought new perspectives concerning the being that the new converts were expected to adhere to. Unlike the traditional Akamba Supreme Being whose worship and reference was limited, the new religion introduced a new supreme being called mwiai whose worship and constant reference was expected of, of all the converts at all times of worship. (Julius Mutwota, 2018). The new religion taught against ancestral worship. Owing to that, it embarked on teaching all its Kamba converts in the district of the need to refrain from referring to their dead ancestors when worshipping. Consequently, the Christian Supreme Being was the only being who was supposed to be referred to during all worship sessions among the converts.

In the Akamba traditional religion, the elderly people were the main source of religious instructions to the rest of the community members (Mutiso Mutua, 2018). All religious knowledge within the community would be passed from one generation to another by the elderly people through methods such as formal teachings or observations. With the introduction of a new religion in the district by the AIM missionaries and the subsequent gradual conversion of the Machakos Akamba to this new religion, there was a new development regarding the source of these religious teachings. Though the role of the elderly people in giving instructions in this new religion cannot be downplayed, a new religious book; the bible was introduced to act as the 


\section{Editon Consortium Journal of Arts, Humanities and Social Studies (ECJAHSS)}

Volume: 02 Issue: 01 | Jan-May-2020

ISSN: $2663-8525$

Received: 07.02.2020; Accepted 10.02.2020; Published: 30.03.2020 at www.editoncpublishing.org

Musyoki, A. Muia et al., Editon Cons. J. Arts., Humanit. S. Stud., Double -Blind Peer Reviewed Journal

principal source of instruction to the Machakos Akamba converts. Though observation as a method of delivering this Christian instruction cannot also be downplayed, preaching became the principal method of delivering these instructions to the new Akamba converts. The new religion held that preaching was the divine truth from the bible spoken with the mouth through the personality of the preacher for the purpose of calling men and women to make a decision for their Supreme Being (AIC Theological Advisory Group, 1991, p.55). Owing to that, there was a gradual change of the adoption of the bible as the main source of religious instructions among the converts which gradually replaced the traditional Akamba methods which were often characterised by a lack of uniformity as they came from different people from different parts of the districts and thus differences in religious teachings were inevitable.

The introduction of a new religion also brought a shift in the management of religious activities in the district. Before the arrival of these missionaries in the district, religious leadership and mobilisation laid in the hands of the experienced members of the community such as the atumia ma nzama (men's council) and the medicine persons. They were the ones who played important roles in guiding the community on matters related to their religion (Aaron Nguta, 2018). However, the introduction of Christianity came with new forms of managing religious institutions in the district. New religious mobilisers such as pastors, evangelists and catechists took over in guiding the converts on matters related to the new religion they had converted into. Qualifications for religious leadership changed from being based on domains such as age and experience to formal training and callings. For instance, in 1945 , for one to qualify to be a licensed pastor to lead the AIM Akamba converts in the district, they had to go for a three-year bible school diploma. In addition, they had to be of a proven character and have a calling to serve the people (Gehman, 2013, p.320). Owing to that, there was a growing tendency of a shift from relying on the traditional Akamba religious leaders to the newly groomed religious leaders from the mission. Councils such as the atumia ma nzama which played a major role in guiding the traditional Akamba during the offering of sacrifices in the shrines were gradually replaced by new councils such as the Local Church Councils (LCCs) and District Church Councils (DCCs) that started to manage the religious affairs of the people. With the continued expansion of the mission in the district, the traditional Akamba religious mobilisers continued to lose their influence on the newly converted members of their community to the newly established AIM mobilisers.

\section{AIM and Transformation of Kamba Rites of Passage}

One of the changes to the Machakos Akamba rites of passage regarded the whole process of birth and naming. The community's ancestral spirits had a great influence on this whole process, and therefore constant recognitions concerning them had to be made before and after birth. This involved honouring them in various ways such as the giving of offerings and naming of the new-borns after them in some instances. With the growing influence of the AIM in the district, there was a gradual change in the way the whole birth and naming process would be conducted in the district, especially to the AIM converts. Firstly, all forms of prenatal and postnatal ancestral worship ended among the converts (Benson Kitinga, 2018). A new belief that ancestral spirits had no influence on the life of an individual before and after birth started to gain a strong hold in the lives of the new AIM believers. The new-born would no longer be considered as a spirit (kiimu), and thus he or she would not be taken through the spiritual transition practices that used to take place before. Some meals such as uki wa mbingi (beer taken to celebrate the birth of a child) continued to lose relevance in the homes of those who embraced the mission's initiatives as the mission strongly opposed any form of beer taking to its converts. Other birth customs such as the kualyula mwana custom as well as the 


\section{Editon Consortium Journal of Arts, Humanities and Social Studies (ECJAHSS)}

Volume: 02 Issue: 01 | Jan-May-2020

ISSN: $2663-8525$

Received: 07.02.2020; Accepted 10.02.2020; Published: 30.03.2020 at www.editoncpublishing.org

Musyoki, A. Muia et al., Editon Cons. J. Arts., Humanit. S. Stud., Double -Blind Peer Reviewed Journal

abstinence of sex during pregnancy gradually declined among the AIM adherents (Patrick Mutala, 2018).

Besides the mission's influence and the consequent changes in birth customs among the Machakos Akamba, there were new developments that influenced the Akamba approach to initiation in the district. These developments can not only be attributed to the new religion in the district but also to the missions other developments in the field of education and health care. Among these new influential developments on initiation made by the mission in the district was the abolition of female circumcision among all its adherents (Gehman, 2013, p.193). In addition, while the mission recognised the importance of male circumcision among its adherents, it put a lot of regulation among its adherents on the matter. The male circumcision could now be arranged by the missionary in charge and the church elders without any heathen ceremonies or practices (Gehman, 2013, p.193). In addition to these new regulations put forward by the mission concerning the convert's approach to the initiation, the mission initiated strict policies on the adherents who violated the initiation regulations. Owing to that, constant suspensions from the church membership were common to the adherents who would go against the mission's stand on the whole process of initiation (Frank, 1984, p.192). With the continuing influence of the AIM in the district, there was a gradual change in the traditional Akamba initiation processes in which the new AIM influences continued to take preeminence in the district.

As a result of the mission's activities in the district, there were also new developments on the marriage rite of passage among the Machakos Akamba. These new developments can be said to be twofold. Firstly, there was the abolition of some Akamba traditional practices that the mission felt went against the ethos of their religion. Secondly, there was the integration of new practices that the mission's adherents would abide with so as to become full members of the newly introduced religion. As a result of the abolition and integration, the marriage rite of passage among the native adherents took a different direction that was non-existent before then.

Before the coming of the mission in the district, the Akamba had a different approach to marriage ceremonies among its community members. The ceremonies that were characterised by feasting, dancing, beer drinking and honouring the dead made the Akamba marriage ceremonies meaningful and complete. With the introduction of a new civilisation by the AIM missionaries, there was a gradual change in the way these ceremonies would be carried on, especially by the mission's adherents. Firstly, the mission taught against some of the Akamba traditional practices that featured in the celebration of this rite of passage. For instance, the mission forbade its adherents from participating in the marriage ceremonies that involved all forms of heathen practices acts such as dancing, honouring the dead and beer drinking (Johnson Mating'i, 2018). In addition, the mission became more involved in the whole process of the performance of this rite of passage among the Machakos Akamba converts. For instance, the mission would regulate the converts' choice of marriage partners. No adherent would be allowed by the mission to marry a person who was not a convert (Ngei Mutala, 2018). During the marriage negotiations between the two families involved, the integration of Christian principles in these negotiations became significant.

The activities of the AIM in Machakos District also influenced the way the Machakos Akamba approached death as the final rite of passage in the community. The death of an individual in the community marked the start of funeral arrangements in the community. One common feature of these arrangements were the customs that the Machakos Akamba observed during this period. With the arrival of the AIM, the observation of these customs started to decline as the mission's influence in the district 


\section{Editon Consortium Journal of Arts, Humanities and Social Studies (ECJAHSS)}

Volume: 02 Issue: 01 | Jan-May-2020

ISSN: $2663-8525$

Received: 07.02.2020; Accepted 10.02.2020; Published: 30.03.2020 at www.editoncpublishing.org

Musyoki, A. Muia et al., Editon Cons. J. Arts., Humanit. S. Stud., Double -Blind Peer Reviewed Journal

intensified. For instance, customs such as the kumya kikwu custom in which the Kamba would drive away death from the bereaved family through sexual intercourse ended among the converts (Julius Mutwota, 2018). In addition, the purification practice which often took place after the burial of the deceased to protect the participants in the burial from carrying with them death to their homes could no longer be practised in the convert's families. This was replaced with the new belief that death was not communicable, and thus the interaction with bereaved persons could not necessarily transmit death to another person (Jonathan Kalii, 2018). Before the introduction of Christianity by the AIM missionaries in the district, there were no well-organised funeral programs for the deceased members of the Akamba community. The organisation of funerals among the Machakos Akamba varied according to the status of the dead person in the community as well as the area of the district in which the death occurred. Some people who were about to die would be carried and be left in the forest to die from there.

Others would be buried near their homesteads in a ceremony, which was often short, less organised, and in most cases, male-dominated (Mbondo Mutiso, 2018). With the developing influence of the AIM in the district through the introduction of a new civilisation, several changes were witnessed in the Machakos Akamba approach to death and funerals. Firstly, the use of prayers coupled with singing as a way of comforting the family of the bereaved converts started to gain momentum among the converts. Once death had occurred in a family of the mission's convert, colleague converts would start converging in the deceased homestead to pray to the Christian Supreme Being who was believed to be a source of comfort to the deceased family. This praying was often accompanied by singing as a way of comforting the bereaved converts. In other instances, bible reading which was often accompanied by preaching skewed towards the Christian teaching of death would accompany the singing and praying (Kalii, 2018).
Upon the setting of the funeral date, the converts would converge in the deceased homestead and offer him a decent Christian send off in which prayer; bible reading, singing and preaching dominated the whole process. There was no restriction on the attendance of these funerals unlike in the traditional Akamba way of officiating funerals in which women, youth and children's attendance was restricted (Muindi, 2018). After the burial, follow up activities which involved constant visits to the family of the deceased converts would be made. In these visits, Christian worship through bible reading, praying, singing and preaching were very dominant. In addition, the converts would attend these visits carrying with them items such as water, firewood and any other items that would be of help and comfort the deceased convert's family (Nzyoka, 2018). All these new developments were mainly influenced by the initiatives of the AIM in the district.

\section{AIM and Transformation in Education}

Before the coming of the mission in the district, the form of education that was popular among the Machakos Akamba was the traditional Akamba type of education that was mainly offered within the home environment. With the coming of the AIM missionaries, there was a huge overhaul of the way education was being carried out in the district that greatly contributed to the literacy transformation that was being witnessed in the district during the mission's reign and beyond. Firstly, there was a shift in the venue for providing this education from the home environment to the school environment. Although this shifting did not mark the end of the provision of education within the home environment, the school as a venue for the provision of education took centre stage (Jonathan Mbwesa, 2018). Consequently, the mission established elementary, intermediate and later secondary schools in many different parts of the district to offer education to the Machakos Akamba. Higher institutions of learning, such as teacher and bible training colleges were also established by the mission to effectively facilitate the delivery of education to 


\section{Editon Consortium Journal of Arts, Humanities and Social Studies (ECJAHSS)}

Volume: 02 Issue: 01 | Jan-May-2020

ISSN: $2663-8525$

Received: 07.02.2020; Accepted 10.02.2020; Published: 30.03.2020 at www.editoncpublishing.org

Musyoki, A. Muia et al., Editon Cons. J. Arts., Humanit. S. Stud., Double -Blind Peer Reviewed Journal

the natives. Among these higher institutions of learning included the Kangundo Teachers' College, and the Ukamba and Mbooni Bible Colleges (Mbondo Mutiso, 2018). Besides the change in the venues of offering this education, there was also the construction of special buildings in the form of classrooms in which teaching and learning were being conducted. This was contrary to the traditional Akamba education, where there were hardly classrooms in which teaching and learning would be conducted (Pius Muindi, 2018).

Another main feature of education transformation in the district initiated by the mission was the introduction of the art of reading and writing among the Machakos Akamba. Before the arrival of the AIM missionaries in the district, the Kamba traditional system of education hardly offered any form of reading and writing to the Machakos Akamba. With the newly introduced system by the mission, the Machakos Akamba who attended these schools learned how to read and write (Mutiso Mutua, 2018). This was a major breakthrough as far as literacy was concerned in the district. Firstly, communication between the AIM missionaries and the natives as well as among the natives themselves became easier. This is because previously, the use of language in communication was only limited to the verbal form of communication. However, when the art of reading and writing was introduced among the Machakos Akamba, the earlier ways of communication were boosted. In addition, new ways of communication, such as the use of letters, became more common among the Machakos Akamba (Patrick Mutala, 2018).

Besides the basic education, that the mission provided in the district through its churches as well as it's elementary, intermediate and later its secondary schools, the AIM also ventured in higher education in Machakos District. This was through the establishment of bible colleges, institutes and teacher training colleges. The first bible institute to be established by the mission in the district was the UBC that was established in 1928. The college that was established in the Mumbuni AIM mission station and later moved to the Katelembo area of Machakos town was mainly offering a theological type of education to the Akamba converts who wished to be leaders in the AIM/AIC church.

In 1952, the mission established a bible institute at the Mbooni mission station, which supplemented UBC in the provision of theological education among the Machakos Akamba who wished to advance their bible knowledge. Ten years later, the mission expanded the provision of theological education in the district by opening the Scott Theological College now Scott Christian University in the Mumbuni mission station. These bible institutes played a major role in training many native converts who wished to be AIM/AIC church leaders in the district and beyond. Consequently, in the 1960s, a couple of graduates from these institutes were working in various parts outside the district. Among these included Timona Itumange from Mukaa area of Machakos District who volunteered in the 1940 s to go and evangelise in the areas unreached by Christianity in Kitui and Tharaka Districts. Another graduate from these theological education institutes who pursued evangelism outside the district's borders was Pastor Paul Mulwa Kisakwa, an AIM/AIC pastor who left the district in the 1940 s and went to evangelise in Kajiado District among the Maasai. Rev. Jeremiah Kyeva Kyaka from Mukaa was among the Akamba missionaries nurtured by the AIM to spread the gospel in Kinango South Coast of Kenya. Other coastal areas that were impacted by AIM nurtured evangelists from Machakos District include Shimba hills, Tudor, Lungalunga and Malindi among others. In the early 1960s, Rev. Peter Mualuko and his wife Rhoda Mualuko who had been stationed by the AIM/AIC in the Kalawa area of the district begun evangelisation activities among the Turkana of Kenya and the Taposa of Southern Sudan (Frank, 1984, p.217-245). The AIM trained evangelists from Machakos District also extended their influence outside Kenya to other countries such as Tanzania, Congo and 


\section{Editon Consortium Journal of Arts, Humanities and Social Studies (ECJAHSS)}

Volume: 02 Issue: 01 | Jan-May-2020

ISSN: $2663-8525$

Received: 07.02.2020; Accepted 10.02.2020; Published: 30.03.2020 at www.editoncpublishing.org

Musyoki, A. Muia et al., Editon Cons. J. Arts., Humanit. S. Stud., Double -Blind Peer Reviewed Journal

Southern Sudan. This is a clear indication that the social transformation brought by the AIM in Machakos District did not only impact the district but also Kenya and its neighbouring states.

Besides the higher education that the AIM provided in the district through the establishment of bible colleges and institutes, we had other higher institutes such as Teacher Training Centres (TTC) established in the district by the mission. Among these TTCs was the Kangundo Teachers' Training Centre (KTTC) that was established by the mission in the late 1940 s for the purpose of training native teachers to curb the rising shortage of teachers in the mission's established schools (KNA, 1949). Consequently, the establishment of this TTC boosted the provision of native education by the mission in the district, as at the end of every year, trained teachers would be deployed to various parts of the mission schools in the district to oversee the implementation of the mission's education.

\section{AIM and Transformation in Health Care}

The arrival of the AIM missionaries in Machakos District marked a change in the way medical and health care provision was carried out in the district. Before the arrival of these missionaries in the district, the provision of medical care was mainly in the hands of the traditional Akamba medicine persons who integrated both physical and spiritual methods to treat different ailments affecting the Machakos Akamba as mentioned earlier in chapter three. With the coming of the AIM missionaries, there was a gradual shift in the way health care matters were being addressed in the district.

One major transformation as a result of the coming of these missionaries was the establishment of central locations in the form of health centres where the Machakos natives would visit for treatment. These health centres were firstly established in the Kangundo, Mumbuni, Mbooni, and the Mukaa mission stations. Before then, the only centres for treatment that the Machakos Akamba would visit were mainly the homes of the traditional Akamba medicine persons (Mbondo Mutiso, 2018). With the establishment of these centres, many Machakos Akamba would daily flock in them for the treatment of various diseases that were affecting them. Treatment for diseases such as influenza, dysentery, smallpox, malaria and pneumatic fever among others that were prevalent in the early years of the mission in the district would now be carried in these newly established AIM health facilities in the district (KNA, 1918-1919). Apart from the medical services that the AIM missionaries would offer in these medical centres located in the mission stations, they would make frequent visits to the villages to treat the natives of various ailments that were affecting them. For instance, as early as 1911, Dr Elwood an AIM missionary stationed in the Mumbuni mission station would travel hundreds of miles in the district to treat people with illnesses related to their eating habits, lifestyle and insufficient clothing in the cold seasons (Gehman, 2013, p.74).

Among the Machakos Akamba, the integration of religion in the prevention, treatment and the curing of various diseases played a major role in the Akamba society health sector. Besides the use of the plants and other naturally occurring substances in the treatment of various ailments, the Akamba would include other measures that were believed to influence the occurrence of these diseases. For instance, the time-to-time sacrificing in the shrines was believed to protect the community from various misfortunes such as diseases (Muthio Munee, 2018). In addition, after the Akamba medicine persons were done with the treatment of a patient by the use of plants and other naturally occurring substances, they would prescribe to him or her some activities or even substances which had a spiritual connotation in them for complete healing. For instance, some amulets given to the Akamba by the medicine persons were believed to protect them from 


\section{Editon Consortium Journal of Arts, Humanities and Social Studies (ECJAHSS)}

Volume: 02 Issue: 01 | Jan-May-2020

ISSN: $2663-8525$

Received: 07.02.2020; Accepted 10.02.2020; Published: 30.03.2020 at www.editoncpublishing.org

Musyoki, A. Muia et al., Editon Cons. J. Arts., Humanit. S. Stud., Double -Blind Peer Reviewed Journal

diseases while others had a healing belief attached to them. Furthermore, through divination, the medicine persons were able to foretell the coming of infectious diseases (Lindblom, 1920, p.287).

Generally, due to the introduction of western medical practices by the AIM missionaries in Machakos District, there was a continued decline in many traditional Akamba medical practices. For instance, the purification services offered by the mundu mue wa ng'ondu started to decline as the mission's education gained popularity in the district (Mbondo Mutiso, 2018). This can be attributed to the enlightenment that came with the missionary education that rendered this practice insignificant among the native elites. In addition, the mission considered this practice antiChristian and thus forbade its converts from participating in it. Other practices that continued to lose relevance among the Machakos Akamba AIM converts was the muti cult. These included the muti wa wia, muti wa wende and the nzevu which the mission also considered anti-Christian and thus discouraged its native adherents from practice (Jonathan Kalii, 2018).

The continued decline in the reliance of the Kamba traditional medicine translated to an increment in the number of natives seeking for the newly introduced western medical practices. For instance, in the Mukaa mission station dispensary, the number of natives seeking medical attention increased from 1349 patients in 1920 to 3887 in 1927. In the Mbooni mission station dispensary, the number of natives that flocked into the mission's dispensary to be treated of various ailments in 1927 alone was 4,315 patients (Gehman, 2013, p.78).

AIM and Transformation in the Concept of Time and its Management among the Akamba

One factor that can be attributed to these new developments in the conception and the management of time in the district was the missionary education. In the schools that the mission established in almost every corner of the district, time was an important aspect in the managing and running of these schools and institutions. Firstly, the new concept of time would be taught by the missionaries in these schools as a topic in the mission school's syllabus (Mbondo Mutiso, 2018). Owing to this, the Machakos Akamba were introduced to new ways of measuring time through the use of various instruments such as watches, clocks and calendars. Parameters such as the minutes and hours became the new tools for determining what time of the day it was. This replaced the observation of the movement of objects such as the moon, the sun or the behaviour of animals to measure time during the day (Patrick Mutala, 2018). The concept of the week was also introduced to the Machakos Akamba. Before then, the Akamba had no idea of this concept. The most common form of measuring time involving a few days was the yesterday(iyoo), today(umunthi), tomorrow(uni) and the day after tomorrow(auke) approach. Nevertheless, a new way of conceptualising time that involved a few days was introduced to the natives in the form of a week of seven days. In the new week concept, each day had its own name in which the natives later translated these new names into the Kikamba language. These new names included Wakwambililya or Wamondi (Monday), Wakeli (Tuesday), Wakatatu (Wednesday), Wakana (Thursday), Wakatano (Friday), Wathanthatu (Saturday), Wakyumwa(Sunday) (Pius Muindi, 2018).

Besides the concept of the week, new ways of measuring time beyond the week such as the month and the year were introduced to the AIM adherents in the mission's schools. Before then, the Akamba had an idea of the concept of the month, which was often measured by the appearance and the movement of the moon (Mutiso Mutua, 2018). With the influence of missionary education, there were new developments concerning the Akamba conception of the month. Consequently, the measurement of time during the month took the form of counting the 


\section{Editon Consortium Journal of Arts, Humanities and Social Studies (ECJAHSS)}

Volume: 02 Issue: 01 | Jan-May-2020

ISSN: $2663-8525$

Received: 07.02.2020; Accepted 10.02.2020; Published: 30.03.2020 at www.editoncpublishing.org

Musyoki, A. Muia et al., Editon Cons. J. Arts., Humanit. S. Stud., Double -Blind Peer Reviewed Journal

number of days which would range from twenty-eight to thirty-one days. A couple of twelve months then formed a year. To improve the effectiveness of measuring time during the month and the year, the calendar was introduced to the natives. Apart from the teaching and learning of these new concepts of time by the Akamba natives in the AIM established schools, the Akamba who interacted with the missionaries either in the school, church or even in the villages were able to learn on the new conception of time as they observed the way these missionaries would conceive time (Mbondo Mutiso, 2018). Consequently, because of these new developments in the conception of time, the Machakos Akamba gradually continued to embrace the new system as their old system of conceiving time continued to take the back seat, especially among the convert elites.

Coupled with the new developments in measuring time was the transformation in the way the Akamba would manage their time. School and church days were introduced among the Machakos Akamba. For instance, during the week, five days would be spent for school attendance for those who had enrolled in the mission's schools while the seventh day was set aside for worship. In the newly introduced religion, this was a day of rest, and all the converts would converge in the mission's churches for the purpose of worship. Before then, there were no specific days for school attendance, rest or worship within the Machakos Akamba society (Mbondo Mutiso, 2018). By observing how events in the school and the church were organised against time, the natives would learn new ways of organising their daily activities against the time available. This was made possible by the programs that had been drawn in the schools in the form of timetables that would often dictate how the daily activities would progress. In addition, there was a bell that would ring to signify the start and the end of the various activities carried out in the schools (Gehman, 2013, p.77).
The integration of other ways of spending time among the Machakos Akamba by the mission also came with the diminution of other ways of spending time that the converts were practising before the arrival of the mission in the district. For instance, the convert would no longer spend his or her time in attending the offering and sacrificial activities in the shrines or even the daily beerdrinking sessions especially among the Atumia among other activities that the mission considered anti-Christian (Jonathan Kalii, 2018). The time that the native convert would spend visiting the traditional Akamba medicine persons when they got sick would be spent visiting the mission's dispensary. Time previously set aside by the community for activities such as the kilumi and wathi would be utilised for other activities as the mission forbade the converts from being part of these activities.

\section{AIM and Transformation in Language and Communication} Because of the initiatives made by the AIM in the provision of education in Machakos District, there was a great revolution in language and communication among the Machakos Akamba. As Allyward has observed, language is the central mechanism of culture. Just like the work of other Christian missions in Africa, the decision by the AIM to promote the Kikamba language as well as introducing the English language did not only help to preserve the Machakos Akamba culture but also lifted them to the modern world and enabled them to communicate with other cultures at the world level (Allyward, 1996, p.26). Among the reasons, why the mission was interested in developing the Kikamba language was that the language was an important tool for helping the missionaries reach the Akamba for evangelisation. One of the major measures that the mission took to develop the Kikamba language, was the establishment of the written form of the Kikamba language. The mission did this through the introduction of Kikamba lessons in all its elementary schools in the district (Mbondo Mutiso, 2018). Through this initiative, the Machakos Akamba natives who enrolled in the mission's 


\section{Editon Consortium Journal of Arts, Humanities and Social Studies (ECJAHSS)}

Volume: 02 Issue: 01 | Jan-May-2020

ISSN: $2663-8525$

Received: 07.02.2020; Accepted 10.02.2020; Published: 30.03.2020 at www.editoncpublishing.org

Musyoki, A. Muia et al., Editon Cons. J. Arts., Humanit. S. Stud., Double -Blind Peer Reviewed Journal

schools would not only learn how to read their language but also put it down in writing. They would get an insight of the phonology, morphology and the syntaxial dimension of their language. Later, when the mission established its first bible college in the district in 1928, missionary Guilding who had then learnt the language would use the Kikamba language as a medium of instruction (Gehman, 2004, p.132).

Another measure taken by the mission to develop the Kikamba language was through the publication of materials in Kikamba. For instance, by 1900 , the AIM missionaries in the district had translated eight hymns into Kikamba. This aided in the singing of these hymns in the Kikamba language in the mission's churches. In 1915, the AIM missionaries published the book of mark in the Christian bible into Kikamba. By 1920, the missionaries had published the whole of the New Testament into Kikamba language (Frank, 1984, p.209-210). Through this, the elite natives would not only read the New Testament on their own but also use it to evangelise to the rest of their members in the community. Among the AIM missionaries who were at the forefront in these translations and publications was C.F. Johnston of the Mumbuni mission station and George Rhoad of the Mbooni mission station. While Rhoad translated the books of Mark, John and Mathew into Kikamba, Johnston managed to translate the book of Luke into Kikamba besides preparing various readers for the same (Gehman, 2013, p.72). Through this, they would minister to the AIM adherents in their respective mission stations and their environs with ease a factor that contributed to the exponential growth of the mission's activities in these areas.

As a way of developing the communication means among the Machakos Akamba, the mission introduced English as a new language that the mission's adherents would learn and communicate in apart from their native language. Although the mission was not the sole contributor in the development of this language in the district, it can be said to have played a key role in the spread of this language in the district as it was taught in all its elementary, intermediate, secondary and later tertiary institutions. Consequently, the introduction of this new language among the Machakos Akamba did ease not only the communication between the AIM missionaries and the natives but also the outside world. As many natives continued to show interest in learning and communicating in the language, the ability to communicate in English became a status symbol, and thus many natives continued to develop an interest in the learning of the language.

\section{AIM and Transformation in Transport Networks}

The coming of the AIM in the district witnessed a change in the development of these transport networks in the district, especially in the areas that the mission had camped by establishing mission stations. Although the AIM was not the major contributor in the construction of these road networks in the district, it can be said to have played a critical role in the whole process of developing road networks in the district. Among the areas of the district that were mainly impacted by the mission's initiative to open the Machakos hinterland to modern means of transport was the Mbooni area. Under the leadership of the AIM missionary George Rhoad, the area witnessed a massive construction of road network that linked the area to the Kilungu and Mumbuni areas of the district.

When George Rhoad arrived in the Mbanya area of Mbooni in 1907, he was riding on a mule because of the nature of the Mbooni terrain and the consequent lack of roads (Paul Mutuku, 2018). After the establishment of the mission station and the subsequent settling in the Mbooni area, apart from evangelism, one of the things that George Rhoad embarked in was the opening of the area through road construction. His main aim being to link the Mbooni area of the district to the Kilungu and Mumbuni areas of the district with better transport system, Rhoad oversaw 


\section{Editon Consortium Journal of Arts, Humanities and Social Studies (ECJAHSS)}

Volume: 02 Issue: 01 | Jan-May-2020

ISSN: $2663-8525$

Received: 07.02.2020; Accepted 10.02.2020; Published: 30.03.2020 at www.editoncpublishing.org

Musyoki, A. Muia et al., Editon Cons. J. Arts., Humanit. S. Stud., Double -Blind Peer Reviewed Journal

the construction of roads and paths that facilitated the easy movement of people living in these areas. By 1909, Rhoad had made about fifty miles of roads in the Mbooni area (KNA, 1909). Among the first road construction projects that were initiated by Rhoad was the road that linked the Mbooni mission station to the Mumbuni mission station via Mutanda, Yiatwa, Kisyani, Kalawani, Tututha, Kyamithenge, Kiima Kimwe to Mumbuni. Another road passed through Kalawani, Ngwasi, Kwa Njema, and Kimutwa. This road met with the other one from the Kilungu area of the district at Katumani area then passed through Katoloni to the government fort at Machakos (Paul Mutuku, 2018). By linking Mbooni area to the Kimutwa area of Machakos, the Mbooni mission station and surrounding environs could now be accessible from the Mumbuni mission station a short distance from the government fort at Machakos. Part of this road network was later developed by the colonial and post-colonial governments in Kenya, and up to the present day, they serve the people of this area by linking them from Machakos to Mbooni and vice versa.

To link the Mbooni area to the Kilungu area of the district, Rhoad initiated the construction of another road via Tuvilani, Kangethani, Ng'alikya, Kikima, Ithamaa, Mwanyani, Utangwa to Kyambalasi were at the present day the Wote Machakos road passes. From Kyambalasi, this road extended to Makongo and Kivani where the mission had temporarily opened a mission station. Later, the road extended to Kola, Kee, Kilungu to the Mukaa mission station. The road construction initiative continued in the surrounding areas of the Mukaa mission station. While most of these constructions were just paths that linked the Mukaa mission station to its splinter mission out schools and churches, we had some major roads whose construction was overseen by the mission in this area. Among these roads was the Mukaa- Uvete road constructed in 1959 to link the Mukaa mission station and Uvete were the mission had various establishments (KNA,
1959). Through its adherents, the mission also initiated the construction of transport networks that linked its other outstations in the area such as Kitaingo, Maiani, Kamuthini and Mumela among others.

Generally, most of the roads found in the areas were the AIM established itself in the district, especially during the colonial period were AIM initiated roads (Paul Mutuku, 2018). These roads played a major role in the lives of the Machakos natives who inhabited these places. Firstly, they were able to reap the benefits of the mission's developments as the mission established schools and health centres in these locations. Social interaction among the natives increased as it became easier for them to travel from one place to another. Consequently, the spread of ideas and information within these areas also improved. This improvement did facilitate not only the growth of the Akamba civilisation but also the assimilation of western civilisations in the Machakos District society.

\section{Transformation in Music and Dance}

The coming of the AIM missionaries in Machakos District had a great influence on Akamba music and dance. This influence can mainly be attributed to the transformation in religious and educational activities that the mission initiated in the district during its tenure. Before the coming of this protestant missionary group in the district, the Akamba had their own conception of music and dances which often rotated around the kilumi and wathi. The arrival of this mission and the consequent influences it made on the Machakos Akamba brought many changes in the way the Akamba convert would celebrate music in his or her community. For instance, the conversion of the Machakos natives to Christianity translated to the abolition of all forms of participation of the convert to either the kilumi or the wathi dances (Julius Mutwota, 2018). As a result, the AIM adherents in the district would not be involved in any form of grouping that was associated with the Akamba traditional kilumi and wathi dances as they 


\section{Editon Consortium Journal of Arts, Humanities and Social Studies (ECJAHSS)}

Volume: 02 Issue: 01 | Jan-May-2020

ISSN: $2663-8525$

Received: 07.02.2020; Accepted 10.02.2020; Published: 30.03.2020 at www.editoncpublishing.org

Musyoki, A. Muia et al., Editon Cons. J. Arts., Humanit. S. Stud., Double -Blind Peer Reviewed Journal

were perceived to be anti-Christian by the mission. This made the kilumi and wathi dances among them unpopular.

The abolition of the wathi and kilumi dances among the AIM converts in Machakos District coincided with the introduction of new forms of western music among the Akamba converts in the form of hymns (Beatrice Mumbi,2018). This music which was religious in nature was mainly made for worshipping the Christian Supreme Being and provided less of entertainment as compared to the Kamba traditional music which was more of entertainment and less of worship. Before the arrival of AIM missionaries in the district, it was normal for the Machakos Akamba to accompany their singing with dancing as well as the playing of different musical instruments. The introduction of hymn music among the AIM adherents did not come with the above accompaniments in the early years of the mission in the district as it was in the traditional Akamba music. As a result, no dancing or instruments would accompany the singing of the newly introduced hymns (Mbondo Mutiso, 2018). In the mission's churches, the singing would be carried out in a standstill position.

The introduction of western music in Machakos District in the form of hymns experienced a transformation as the mission continued to expand in the district. When the mission was in the initial stages of establishing itself in the district, most of these hymns were still in the English language in which many native converts rarely understood them. To facilitate the full implementation of this new music to the converts, the mission embarked on translating the hymns into the Kikamba language (Gehman, 2013, p.124). Consequently, many AIM adherents were able to sing these hymns in their language, thus internalising the content of the music with ease. Later in the last quarter of the mission's tenure in the district, various developments relating to this newly introduced music in the district were witnessed. Among these developments was the introduction of choruses that supplemented the singing of hymns in the mission's churches (Julius Mutwota, 2018). In addition, structured ways of singing which involved particular groups such as choirs started to crop up in the mission's churches. Consequently, it was common to find groups of the mission's adherents practising choir music in the church compound on particular days of the week. These choir groups explain the origin of town choirs, such as the Machakos town choir in the formative years of Christian influence in the district (Jonathan Kalii, 2018).

\section{Transformation in Architecture and Clothing}

The AIM played a prime role in the development of new forms of shelter and clothing among the Machakos Akamba. Before the coming of this mission in the district, the most common forms of housing in the Machakos Akamba homesteads were the musonge and the kisukuu shelters which were often made up of materials such as tree poles, grass, strings and mud (Ann Nthemba, 2018). With the introduction of a new civilisation in the district by this mission, there was a gradual rise of new forms of architecture in the district. These new forms took the form of western architectural designs that were hardly present in many parts of the district before the arrival of the mission (Mutiso Mutua, 2018). Consequently, the arrival of this mission in the district sparked growth in these western architectural designs. Although we had other western agents such as the colonial government and other missions such as the HGM that played a role in the development of these designs, the AIM can be said to be the major contributor in the spread of these designs in the district as by the end of the missions tenure in the district in 1971; the mission was the leading western agent in the development of these designs in Machakos district. This was because of the high number of structures of this type that the mission had established in the district in the form of prayer houses, health centres and schools by 1971 (Frank, 1984, p.363-368). The high number of such structures established by the mission in the district meant that the mission had a high 


\section{Editon Consortium Journal of Arts, Humanities and Social Studies (ECJAHSS)}

Volume: 02 Issue: 01 | Jan-May-2020

ISSN: $2663-8525$

Received: 07.02.2020; Accepted 10.02.2020; Published: 30.03.2020 at www.editoncpublishing.org

Musyoki, A. Muia et al., Editon Cons. J. Arts., Humanit. S. Stud., Double -Blind Peer Reviewed Journal

following and thus a tremendous influence among the Machakos Akamba.

The AIM mission stations and other mission's establishments were the centres of the spread of these western architectural designs among the Machakos Akamba (Pius Muindi, 2018). In these centres, the mission constructed houses using materials that had hardly been used by the Machakos Akamba before. It was common to find houses made up of brick walls and timber or metal roofs. Outside these houses, there were concrete water tanks that had been built for harvesting and storage of rainwater for use within that particular mission centre (Frank, 1984, p.162). Special care and maintenance could be taken on these houses. These included regular cleaning by the servants taken from the Akamba villages and employed by the mission to perform various duties in the stations.

Apart from the transformations experienced in the district because of the growing developments of new shelter designs, the AIM also influenced how the Machakos Akamba would dress. Before then, many Machakos Akamba mainly wore their traditional attire that involved the use of items such as hides as clothing (Mutiso Mutua, 2018). With the arrival of the mission in the district, there was a growing change in the way of dressing of the Akamba. The AIM did this through a variety of ways. Firstly, the education and religion offered by the mission influenced the Akamba to embrace these new forms of clothing. As one informant observed, in many instances, it was easy to identify a native who had embraced the mission's initiatives in the district and the one who had not through the kind of clothing they wore. While the natives who had embraced the mission's initiatives wore clothes of foreign origin, the one who had not, in many instances wore the traditional Akamba clothing (Aaron Nguta, 2018).

Besides the influences made by the mission's initiatives to cloth the Machakos Akamba in the western styles of dressing, the mission went ahead to provide some of its adherents with cloths. For instance, as early as 1911, Mrs Ellwood Davis an AIM missionary stationed in the Mumbuni mission station was training women from the area on how to sew their own clothes (Gehman, 2013, p.203). This not only boosted the mission's efforts to indigenise the western dressing codes among the Machakos Akamba but also improved the social status of the converts who embraced the mission's initiative. By the end of the mission's tenure in the district in 1971, most of its adherents had embraced the western styles of dressing as a result of various forces most of them initiated by the mission's transformative agenda in the district.

\section{CONCLUSION}

This study has discussed the social developments that were influenced by the coming of the AIM missionaries in Machakos District. This has been done through the examination of the various elements of Akamba social life before and after the coming of the AIM missionaries in the district. The study has demonstrated that the AIM really influenced the different spheres of the Akamba social life such as their religion, rites of passage, education, medicine and health care, the conception of time, language and communication, music and art and architecture among others. This influence took various forms ranging from the introduction and the integration of new ways of approaching various social issues in the Akamba society to the improvement of the existing ones that saw the society transformed largely by the time the mission officially exited the missionary field in the district in 1971.

\section{RECOMMENDATIONS}

In the course of the study, there were new insights that emerged which could not be addressed adequately in this study. Consequently, further research can be directed to a number of areas. Firstly, little research is available on the rise of independent Christian groups that were born out of the AIM in Machakos District. Despite the rise of these 


\section{Editon Consortium Journal of Arts, Humanities and Social Studies (ECJAHSS)}

Volume: 02 Issue: 01 | Jan-May-2020

ISSN: $2663-8525$

Received: 07.02.2020; Accepted 10.02.2020; Published: 30.03.2020 at www.editoncpublishing.org

Musyoki, A. Muia et al., Editon Cons. J. Arts., Humanit. S. Stud., Double -Blind Peer Reviewed Journal

splinter groups such as the ABC, GFBC and the GNCA (Good News Church of Africa) among others, there is little research on the matter. Secondly, the influence of other missionary groups such as the Roman Catholic HGM and other Roman Catholic-affiliated groups in Machakos District needs to be studied. This is because this influence has not been studied in a significant manner despite the Roman Catholic Church being one of the stiff missionary competitors of the AIM in the district. Further, there is a need to study the influence of the AIC among the Machakos Akamba after the exit of the AIM in the district. This is because the church continued to intensify its influences among the natives of the district despite the lack of substantial studies of these influences.

\section{References}

AIC Theological Advisory Group. (1991). Worship Guide for Pastors and Elders: How to Improve the Worship in the AIC Church. Kijabe: Kesho Publications.

Allyward, S. (1996). Christianity and the African Imagination. Nairobi: Paulines Publication in Africa.

Anderson, J. (1970). The Struggle for the School: The Interaction of the Missionary, Colonial

Barret, B. D., \& Mambo, K.G.(1973). Kenya Churches Handbook: The Development of Kenyan Christianity. Kisumu: Evangel Publishing House.

Frank, F. (1984). Between Two Mountains: A pilgrimage from Kamba Traditional Beliefs to Christian Community1895-1970. Scarborough, Thomas Nelson Publishers.

Gehman, R. (2004). The African Inland Mission: Aspects of its Early History. African Journal of Evangelical Theology, 23(2) (2004), 115-132.

Gehman, R. (2013). From Death to Life: The Birth of the African Inland Church in Kenya,1895-1945. Michigan: C-M Books Publishers.

Government and Nationalist Enterprise in the Development of Formal Education in Kenya. Nairobi: Longman Publishers.

Kenneth, R. (1968). Garden of Miracles: A History of the African Inland Mission. London: Victory Press.

KNA, DC/MKS/1/1/1, Machakos District Annual Report, 1909.

KNA, DC/MKS/1/1/30, Machakos District Annual Report, 1949.

KNA, DC/MKS/3/261, Mukaa Locational Council Minutes, 1959.

KNA, PC/CP/1/3/2, Machakos District Annual Report, 1911.

O.I, Benson at Nzyoka at Mbooni on 6/8/2018.

O.I, Jonathan Kalii at Kalamba on 17/8/2018.

O.I, Pius Muindi at Kilungu on 16/8/2018. 